\title{
Supramolecular complexes of kinetin and adenin with glycyrrisic acid and its monoammonium salt
}

\author{
B.Y. Matmuratov ${ }^{\star}$, S.D. Madraximova**, R.S. Esanov*,**, E.U. Eshchanov***, A. D. Matchanov*** and Sh. M. Xakberdiev**** \\ Khorezm Akademy of Mamun, Khiva, Uzbekistan \\ *Faculty of Chemistry, National University of Uzbekiston Named after Mirzo Ulugbek, Tashkent, Uzbekistan \\ **Institute of Bioorganic Chemistry Named after Academician A.S. Sadykova AN RUz. Tashkent, Uzbekistan \\ ***Department of Chemistry, Urgench State University, Urgench, Uzbekiston \\ ****Jizzax Polytechnic Institute, Jizzax, Uzbekistan
}

\section{Article Info}

Article history

Received 17 August 2021

Revised 3 October 2021

Accepted 4 October 2021

Published Online 30 December 2021

\section{Keywords}

Monoammonium salt of glycyrrhizic

Acid

Glycyrrhizic acid

Supramolecular complex

Isomolar series

Antibate ratio

Infrared

Ultraviolet spectroscopy

\begin{abstract}

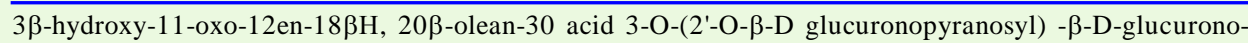
pyranoside (glycyrrhizin acid, GA) - the main active principle of licorice root (Glycyrrhiza glabra L.), which grows on the territory of the Republic of Uzbekistan and is a renewable natural source. Being capable of self-organization and recognition of other particles and molecules, the natural biologically active compounds are the subject of ongoing chemical research aimed to simulate a variety of biochemical processes. In particular, it has been shown that the dilute aqueous solutions of complexes of GA and its monoammonium salt (MASGA) with some low molecular weight compounds significantly affect the germination, development and productivity of crops.

The article presents the results of studying the dependence of the complexation of MASGA with adenine and kinetine depending on the structural changes of the guest molecule. The new supramolecular complexes of GA, MASGA with adenine and kinetine have been prepared by the liquid-phase method, their physicochemical and spectral characteristics have been determined. Using ultraviolet (UV) spectrophotometry, the complex formation of MASGA with adenine and kinetine in aqueous solutions at $\mathrm{pH} 7.2$ has been studied. It was shown that the stability of complexes increases in the series (MASGA: adinine) $(2.07 \pm$ $0.1)^{*} 10^{5}$ M-1< MASGA: kinetine $(5.07 \pm 0.1)^{*} 10^{5}$. And does not depend on the stoichiometric ratio of complexing components. It is assumed that the supramolecular complexes are stabilized by a hydrogen bond, formed between the functional groups of the guest-host molecules, weak intermolecular interactions such as hydrophobic interactions and others.
\end{abstract}

\section{Introduction}

The rapidly developing supramolecular chemistry has made possible to develop methods for molecular encapsulation of a number of drugs and to study the structure of the obtained complexes in order to determine their stability. One emerging way to create low-dose drugs is to prepare clathrates in the presence of glycosides from these locally available plant materials. Molecular complexes obtained in the presence of plant glycosides lead to an increase in water solubility, bioavailability of drugs and the formation of a wide spectrum of biological activity (Tolstikova et al., 2007; Tolstikov et al., 2007).

The biological activity of modifications with glycyrrhizic acid (GA) is determined by the peculiarities of their chemical structure. In order to create new pharmaceutical products, research is being conducted to obtain complexes of glycyrrhizic acid with amino acids, alkaloids, antibiotics, etc. Among them, there are known drugs that have anti-inflammatory, analgesic, antiallergic, hypolipidemic,

Corresponding author: Dr. B.Y. Matmuratov Khorezm Akademy of Mamun, Khiva, Uzbekiston E-mail: b.matmurotov@mail.ru Tel.: +99-8946459166

Copyright (c) 2021 Ukaaz Publications. All rights reserved.

Email: ukaaz@yahoo.com; Website: www.ukaazpublications.com antioxidant, antitoxic, hepatoprotective, immunotropic, antimicrobial and antitumor activities (Tolstikov et al.,1991; Medetbekov et al., 2007; Kondratenko et al., 2003; Yakovishin et al., 2017; Yakovishin et al., 2014).

In his research, the Russian Scientist, L.A. Yakovishin obtained supramolecular complexes of glycyrrhizic acid (GA) and its monoammonium salt (MASGA) with L-histidine, streptocide, caffeine, quercetin, and a number of other biologically active substances. The structures were studied using spectroscopic methods. In addition, the stability constants of the obtained complexes and the Gibbs free energy values were determined by the isomolar series method (Yakovishin et al., 2016; Yakovishin et al., 2014; Yakovishin et al., 2017; Yakovishin et al., 2019).

Adenine is a component of adenine DNA and RNA; it is involved in the formation of adenosine triphosphate, the energy source of the cell (Naseem et al., 2014).

Kinetin (N6-furfuryladenine) is a growth factor and is one of the most widely used ingredients in many skin care cosmetics. There is also some information about the antiplatelet aggregation factor, which reduces the formation of blood clots in the human body, and its ability to correct RNA-related genetic diseases (Hwang et al., 2012). 
Based on the above data, one of the current topics is the modification of adenine and kinetin with GA and its salts and the study of their biological activity.

\section{Materials and Methods}

\subsection{Chemicals and reagents}

Organic solvents: acetone (chemical clean), ethyl alcohol (chemical clean), glacial acetic acid (chemical clean), benzene (chemical clean), acetonitrile (chemical clean), chloroform (chemical clean), ammonium hydroxide (25\%), hexane (chemical clean) and sodium hydroxide (chemical clean). To compose the isomolar series, we used $10^{-4} \mathrm{M}$ aqueous solutions of fitogormons and MASGA (buffer $\mathrm{Na}_{2} \mathrm{HPO}_{4}$ $\mathrm{NaH}_{2} \mathrm{PO}_{4} \mathrm{pH}$ 7.2).

\subsection{Instruments}

IR spectra of the complexes formed in $\mathrm{KBr}$ tablets, were obtained on a Perkin Elmer spectrophotometer (USA). UV spectrophotometer Shimadzu 12.80 (quartz cuvette $10 \times 10 \mathrm{~mm}$ ); HPLC was performed on chromatography Agilent Thechnologies 1200 (USA). Chromatographic analysis conditions: Column - Poroshell 120 EC$\mathrm{C} 18,2.7 \mu \mathrm{m}, 3.0 \mathrm{X} 100 \mathrm{~mm}$, and detector - diode array detector (UV detector can also be used), eluent - acetonitrile: $0.5 \%$ acetic acid (35:65, isocratic method)., flow rate $-0.75 \mathrm{ml} / \mathrm{min}$, detection $-254 \mathrm{~nm}$, amount injected into the column - $10 \mu \mathrm{l}$, oven temperature - 250C, analysis time-15 min. Magnetic stirrer MM-5; rotary evaporator IR-1M2. Lyophilic device Automatic FREEZE-Dryer10010; the melting point was determined on a PTP TU 25-11-1144 device. For thin layer chromatography (TLC), we used silufol plates (Czech Republic).

\subsection{General method of obtaining molecular complex}

Preparation of supramolecular complexes of kinetine with MASGA in a 1:2 ratio. A weighed portion of $1.68 \mathrm{~g}$ of MASGA $\left(2 \times 10^{-3} \mathrm{~mol}\right)$ was dissolved in $25 \mathrm{ml}$ of a $50 \%$ aqueous solution of ethanol at 50$60^{\circ} \mathrm{C}$. Then added $0.22 \mathrm{~g}\left(1 \times 10^{-3} \mathrm{~mol}\right)$ of kinetine, followed by vigorous stirring on a magnetic stirrer for 6-7 $\mathrm{h}$ at room temperature. After that, the organic part was removed from the reaction mixture on a rotary evaporator, and the aqueous part was freeze-dried.

The same method was used to synthesize molecular complexes of adenine, kinetine and GA, MASGA, in a 1:2, 1:4, 1:9 ratio. For this, GA, MASGA were first obtained and purified from technical GA on the basis of certain methods described in the literature (Kondratenko et al., 2005; Stolyarova et al., 2008). On the basis of the obtained GA, MASGA, a number of molecular complexes with kinetin were obtained (Scheme 1).

To obtain the complexes, GA was dissolved in $96 \%$ ethyl alcohol and then a kinetin solution was added to it with vigorous stirring. The alcoholic part is distilled under vacuum and the aqueous part was dried by a lyophilic method. Certain physicochemical characteristics of the obtained molecular complexes have been determined and their optical spectral (UV, IR) properties have been studied in order to study the complex formation process. The data obtained are shown in Table 1 and Figure 1.

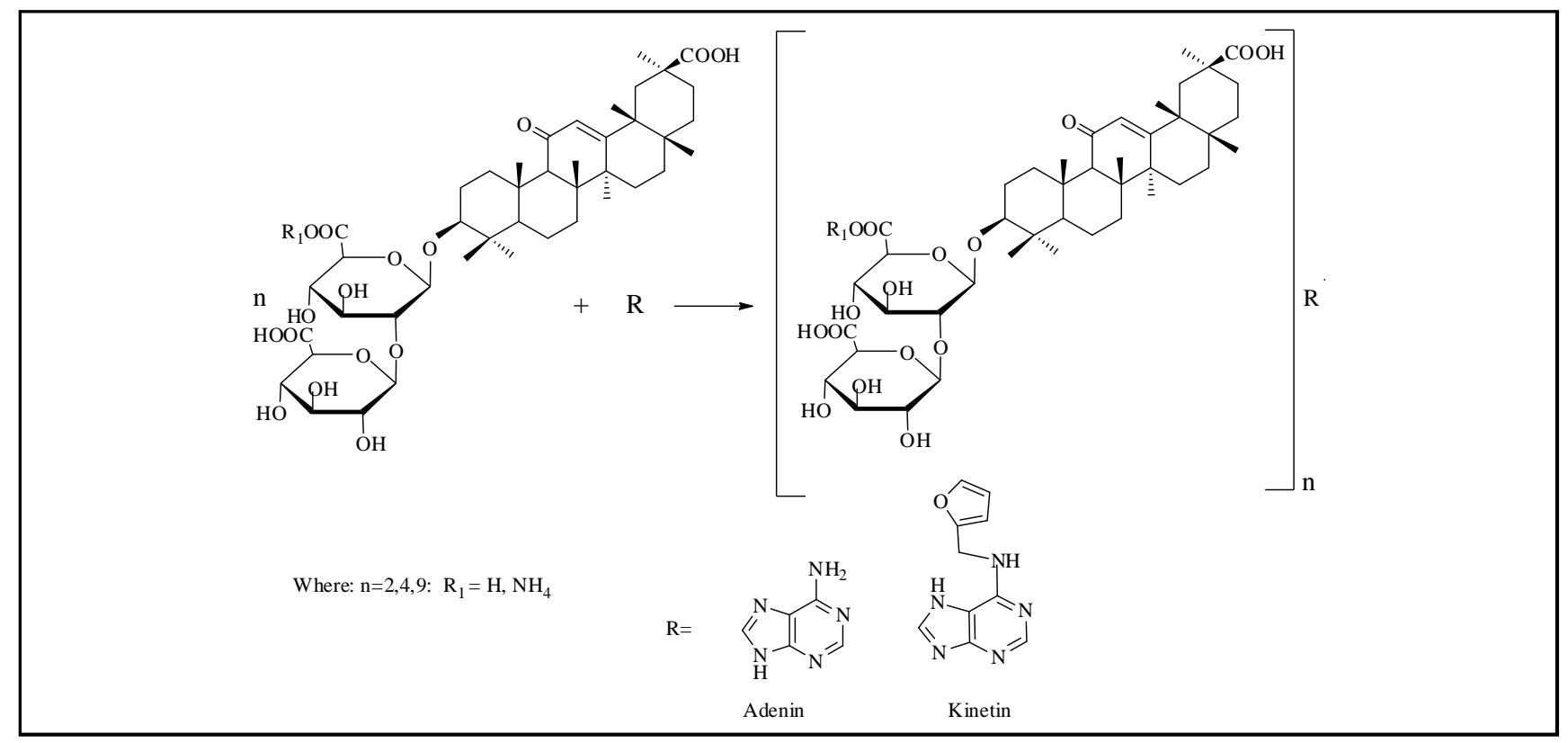

Scheme 1: General scheme for the preparation of supramolecular complexes of adenine and kinetine with GA, MASGA.

\section{Results}

3.1 Study of the formation of supramolecular complexes based on optical spectroscopy methods

It can be seen from the data given in Table 1 and depicted in Figure 1 that in the IR spectra of the obtained compounds, the frequencies of valence vibrations of $\mathrm{OH}$ groups in the GA molecule were observed in the form of a wide shoulder in the region of 3368 $\mathrm{cm}^{-1}$. The frequencies of valence vibrations of the $\mathrm{CH}_{3}$ and $\mathrm{CH}_{2}$ groups were observed in the region of $2924-2868 \mathrm{~cm}^{-1}$, as well as the frequencies of valence vibrations of the carbonyl part of the carboxyl groups in the GA molecule were observed within $1713 \mathrm{~cm}^{-1}$.

The frequency of valence vibrations of the carbonyl group located on C-11 in the aglycone part of the GA molecule was intense in the region of $1656-1653 \mathrm{~cm}^{-1}$. 
Table 1: Some physicochemical and spectral parameters of supramolecular complexes

\begin{tabular}{|c|c|c|c|c|c|}
\hline No. & $\mathbf{R}_{1}$ & $\overline{\mathbf{n}}$ & mp. ${ }^{\circ} \mathbf{C} \quad($ decomposition $)$ & $\mathrm{UV} \lambda_{\text {max }}, \mathrm{nm} \lg \varepsilon$ & Frequencies of vibrations in the IR spectrum, $6 \mathrm{~m}^{-1}$ \\
\hline 1. & $\mathrm{H}$ & 2 & 206 & $264(4.46)$ & $\begin{array}{l}v(\mathrm{OH}, \mathrm{NH})=3339, v\left(\mathrm{CH}_{3}, \mathrm{CH}_{2}, \mathrm{CH}\right)=2928, v(\mathrm{C}=\mathrm{O})=1718, \\
v(\mathrm{C}=\mathrm{O})=1653\left({ }^{11} \mathrm{C}=\mathrm{O}\right), v(\mathrm{C}=\mathrm{C}, \mathrm{C}=\mathrm{N})=1593, \delta\left(\mathrm{CH}_{3}, \mathrm{CH}_{2},\right. \\
\mathrm{CH})=1456,1386,13461259,1213,1163, \delta(\mathrm{O}-\mathrm{H})=1043, \\
\delta(\mathrm{CH}=)=982\end{array}$ \\
\hline 2 . & $\mathrm{H}$ & 4 & 204 & $261(4.54)$ & $\begin{array}{l}v(\mathrm{OH}, \mathrm{NH})=3339, v\left(\mathrm{CH}_{3}, \mathrm{CH}_{2}, \mathrm{CH}\right)=2930, v(\mathrm{C}=\mathrm{O})=1728, \\
1699, v(\mathrm{C}=\mathrm{O})=1651\left({ }^{11} \mathrm{C}=\mathrm{O}\right), v(\mathrm{C}=\mathrm{C}, \mathrm{C}=\mathrm{N})=1591, \delta\left(\mathrm{CH}_{3},\right. \\
\left.\mathrm{CH}_{2}, \mathrm{CH}\right)=1456,1387,1261,1213,1168, \delta(\mathrm{O}-\mathrm{H})=1044, \\
\delta(\mathrm{CH}=)=982\end{array}$ \\
\hline 3. & $\mathrm{H}$ & 9 & 202 & $260(4.07)$ & $\begin{array}{l}v(\mathrm{OH}, \mathrm{NH})=3368, v\left(\mathrm{CH}_{3}, \mathrm{CH}_{2}, \mathrm{CH}\right)=2938, v(\mathrm{C}=\mathrm{O})=1717, \\
1699, v(\mathrm{C}=\mathrm{O})=1651\left({ }^{11} \mathrm{C}=\mathrm{O}\right), v(\mathrm{C}=\mathrm{C}, \mathrm{C}=\mathrm{N})=1591, \delta\left(\mathrm{CH}_{3},\right. \\
\left.\mathrm{CH}_{2}, \mathrm{CH}\right)=1456,1387,1362,1260,1213,1169, \delta(\mathrm{O}-\mathrm{H})= \\
1043, \delta(\mathrm{CH}=)=982\end{array}$ \\
\hline 4. & $\mathrm{NH}_{4}$ & 2 & 190 & $280(4.47)$ & $\begin{array}{l}v(\mathrm{OH}, \mathrm{NH})=3200, v\left(\mathrm{CH}_{3}, \mathrm{CH}_{2}, \mathrm{CH}\right)=2947,2878 v(\mathrm{C}=\mathrm{O}) \\
=1703, v(\mathrm{C}=\mathrm{O})=1622\left({ }^{11} \mathrm{C}=\mathrm{O}\right), v(\mathrm{C}=\mathrm{C}, \mathrm{C}=\mathrm{N})=1589, \delta\left(\mathrm{CH}_{3},\right. \\
\left.\mathrm{CH}_{2}, \mathrm{CH}\right)=1446,1416,1304,1254,1213, \delta(\mathrm{O}-\mathrm{H})=1040, \\
\delta(\mathrm{CH}=)=980\end{array}$ \\
\hline 5. & $\mathrm{NH}_{4}$ & 4 & 192 & $262(4.60)$ & $\begin{array}{l}v(\mathrm{OH}, \mathrm{NH})=3198, v\left(\mathrm{CH}_{3}, \mathrm{CH}_{2}, \mathrm{CH}\right)=2941,2864 v(\mathrm{C}=\mathrm{O}) \\
=1705, v(\mathrm{C}=\mathrm{O})=1620\left({ }^{11} \mathrm{C}=\mathrm{O}\right), v(\mathrm{C}=\mathrm{C}, \mathrm{C}=\mathrm{N})=1589, \delta\left(\mathrm{CH}_{3},\right. \\
\left.\mathrm{CH}_{2}, \mathrm{CH}\right)=1454,1417,1390,1362,1304,1279,1213, \\
1157, \delta(\mathrm{O}-\mathrm{H})=1039, \delta(\mathrm{CH}=)=980\end{array}$ \\
\hline 6. & $\mathrm{NH}_{4}$ & 9 & 194 & $260(4.43)$ & $\begin{array}{l}v(\mathrm{OH}, \mathrm{NH})=3196, v\left(\mathrm{CH}_{3}, \mathrm{CH}_{2}, \mathrm{CH}\right)=2978,2880 v(\mathrm{C}=\mathrm{O}) \\
=1705, v(\mathrm{C}=\mathrm{O})=1645\left({ }^{11} \mathrm{C}=\mathrm{O}\right), v(\mathrm{C}=\mathrm{C}, \mathrm{C}=\mathrm{N})=1589, \delta\left(\mathrm{CH}_{3},\right. \\
\left.\mathrm{CH}_{2}, \mathrm{CH}\right)=1456,1418,1387,1261,1213,1167, \delta(\mathrm{O}- \\
\mathrm{H})=1034, \delta(\mathrm{CH}=)=980\end{array}$ \\
\hline
\end{tabular}

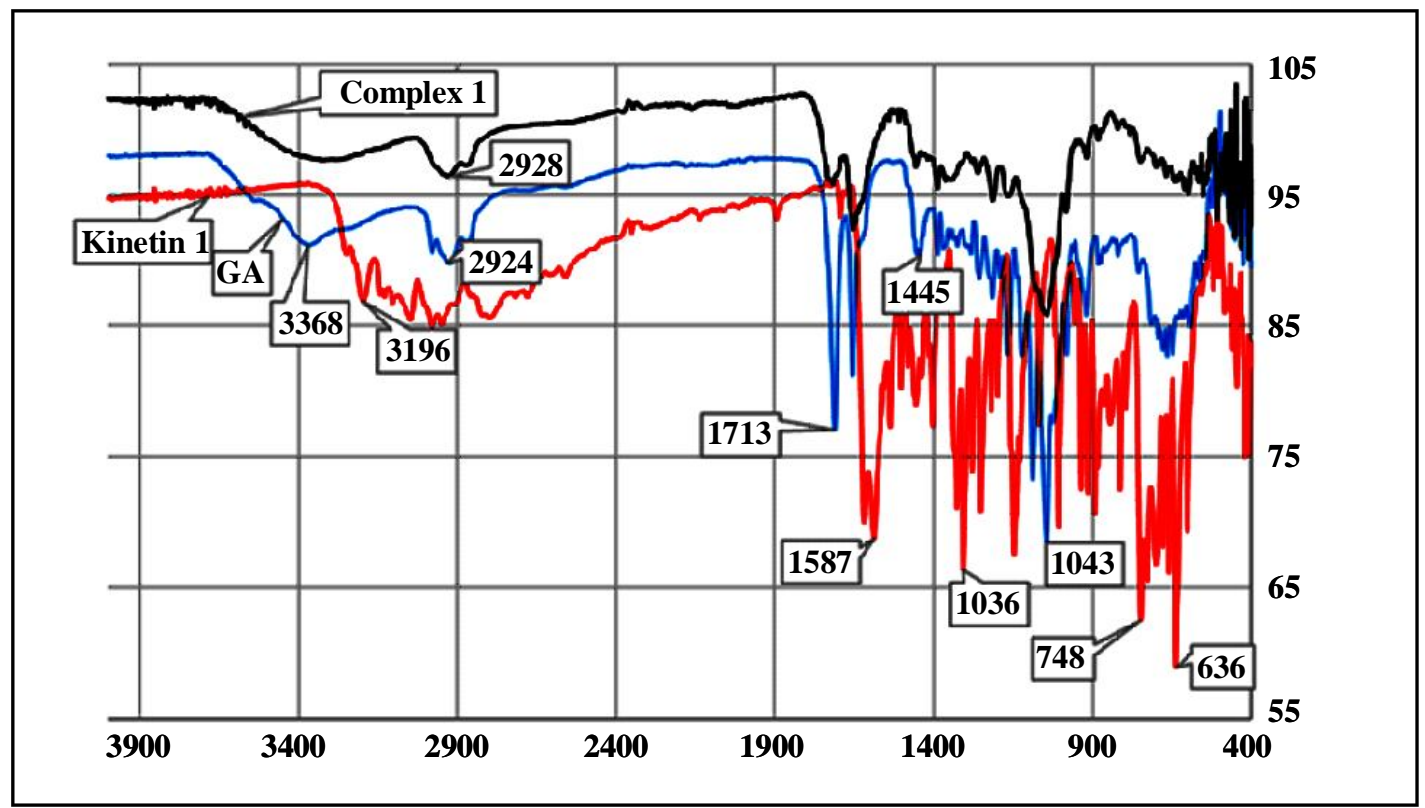

Figure 1: IR spectrum of GA complex: kinetin and GA, kinetin. 
The frequency of the deformation vibrations of the $\mathrm{CH}_{3}, \mathrm{CH}_{2}$ groups are formed in the range of 1446-1143 $\mathrm{cm}^{-1}$. The frequency of valence vibrations of $\mathrm{C}-\mathrm{O}-\mathrm{C}$ and $\mathrm{C}-\mathrm{OH}$ bonds in the molecule was observed in the ranges of $1087-1043 \mathrm{~cm}^{-1}$, and the frequencies of deformation vibrations of the group $(=\mathrm{CH})-$ in the field of $985-975 \mathrm{~cm}^{-1}$.

The frequencies of valence vibrations belonging to the - $\mathrm{NH}$ group in the kinetin molecule were observed at $3198-3193 \mathrm{~cm}^{-1}$, and the frequencies of vibrations belonging to the $-\mathrm{C}=\mathrm{N}$ bonds were observed in the region of $1592-1588 \mathrm{~cm}^{-1}$.

Based on the change in the basic frequencies of the functional groups in the IR spectra of the starting substances, we can assume what types of interactions exist between the molecules in the formation of supramolecular complexes. Since, the frequencies of valence vibrations of $\mathrm{OH}$ groups in the GA molecule were observed in the region of 3370-3364 $\mathrm{cm}^{-1}$, and in the complex of 3342-3335 $\mathrm{cm}^{-1}$.

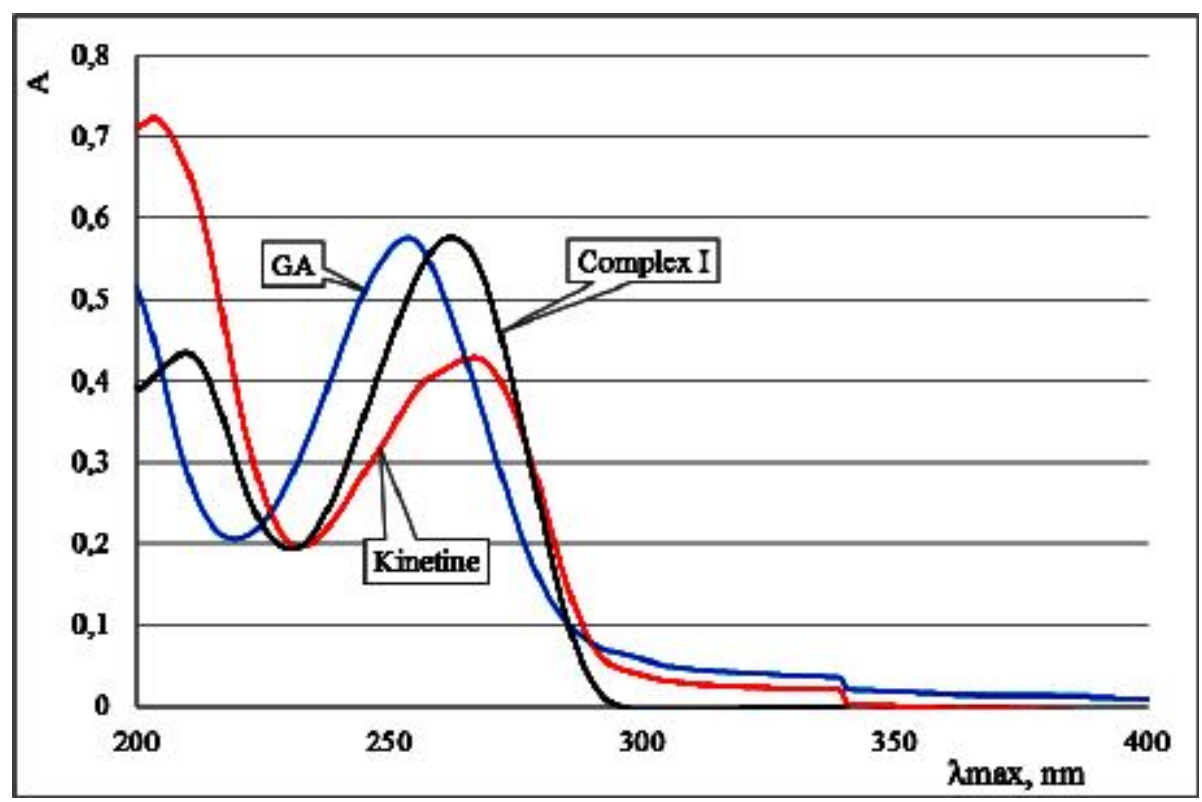

Figure 2: UV spectra of the supramolecular complex of GA:kinetin and GA, kinetin.

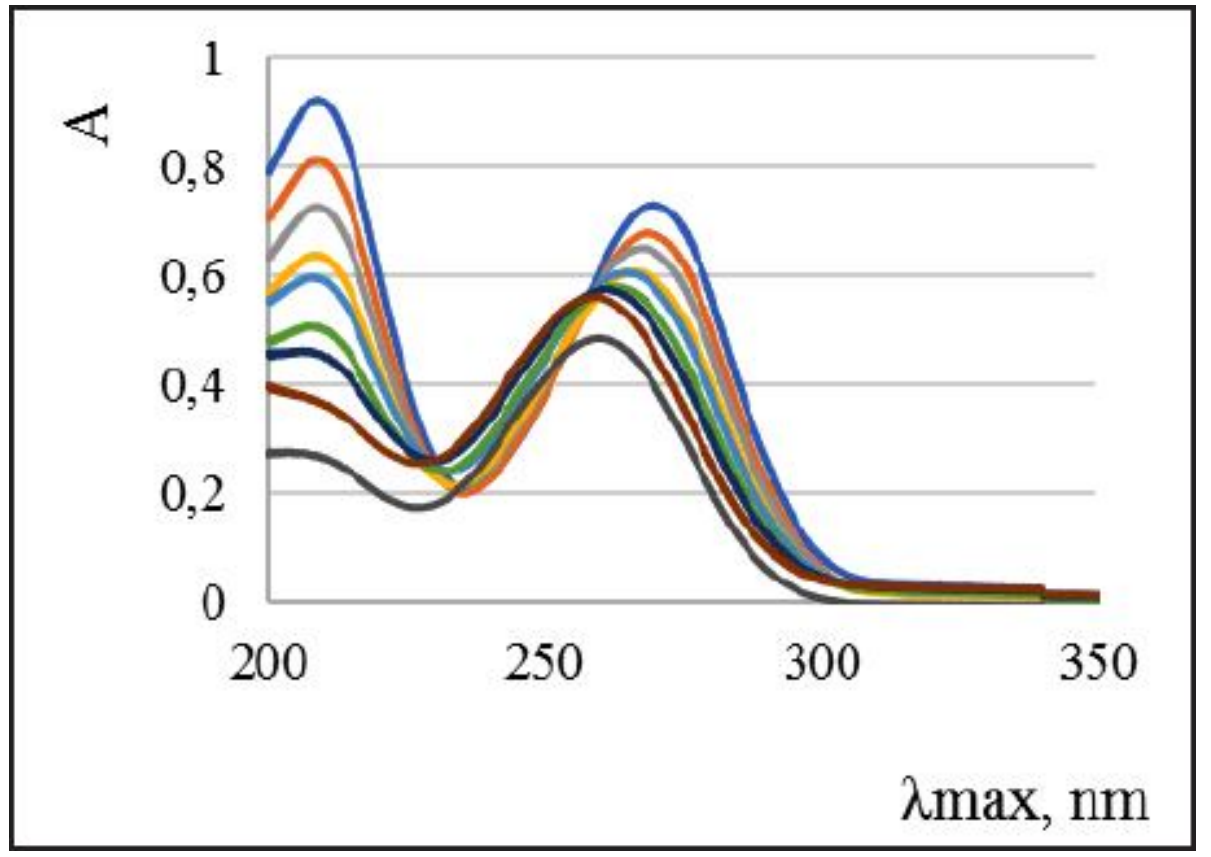

Figure 3: UV spectra of the isomolar series method of the supramolecular complex MASGA and kinetin. 


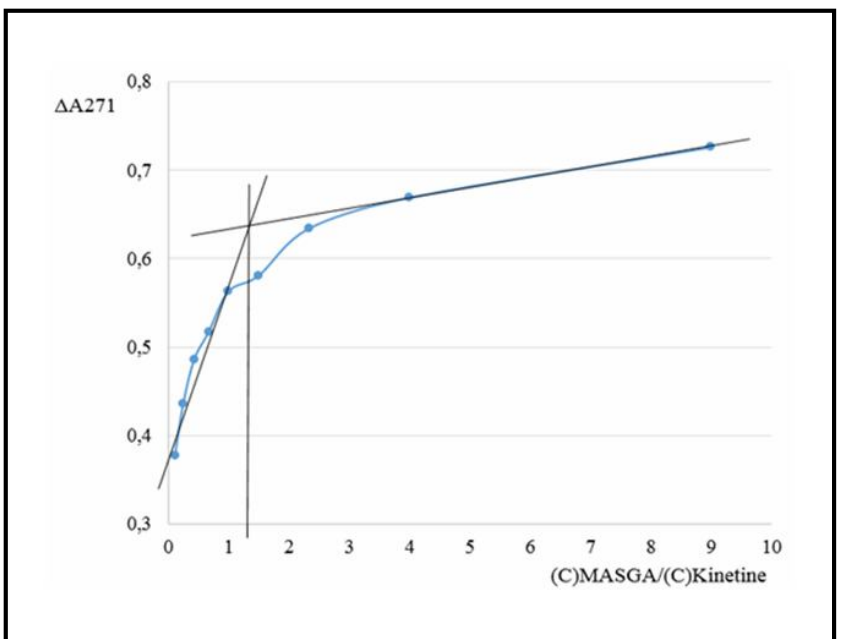

Figure 4:Graph of dependence between the optical density of the isomolar series of the complex of MASGA and kinetin on the concentration of reagents.

In the UV spectrum of GA, the maximum absorption was observed in the wavelength range of $252 \mathrm{~nm}$ (Figure 2), associated with the transition of $n \rightarrow x^{2}$ electrons between the carbonyl group in the $\mathrm{C}$ ring of the GA molecule and the conjugate in the conjugate state (Tolstikov et al., 2007).

3.2 Determination of the stability of complexes by the method of isomolar series

By the method of isomolar series (Ostromyslensky-Job method) was determined the stoichiometric ratios of the components of supramolecular complexes: GA, MASGA, kinetin, and adenine (Bulatov et al., 1986).

In the isomolar series method, solutions of two components ("guest" and "host") with the same molar concentration $\left(10^{-4} \mathrm{M}\right)$ are first conducted determination of the stability constant and the Gibbs free energy of the complexes and the reagents are mixed in ratios ranging from 1:9 to $9: 1$. This in turn maintains a constant solution volume and total reagent concentration $\left(\mathrm{V}_{M}+\mathrm{V}_{\mathrm{R}}=\right.$ const; $\mathrm{C}_{\mathrm{M}}+\mathrm{C}_{\mathrm{R}}$ $=$ const .

To maintain the ionic strength and the $\mathrm{pH}$ constant of solutions, a buffer system (phosphate buffer $\mathrm{Na}_{2} \mathrm{HPO}_{4}-\mathrm{NaH}_{2} \mathrm{PO}_{4}, \mathrm{pH}$ 7.2) is used. The prepared solutions for the isomolar series were mixed in an incubator mixer for $40 \mathrm{~min}$ at a constant temperature $\left(20^{\circ} \mathrm{C}\right)$. The obtained data are shown in Figure 3.

As can be seen from the data in Figure 4, there are isobestic points at 227 and $262 \mathrm{~nm}$. The presence of these isobestic points indicates the formation of similar complexes in the solution. In general, the equilibrium constant can be expressed as follows:

$$
\mathrm{K}=\frac{[\text { MASGA }- \text { Kinetin }]}{[\text { MASGA }][\text { Kinetin }]}
$$

From the graph of the relationship between the optical density of the obtained isomolar series and the concentration ratio of the initial reagents, it is possible to determine the molar ratio of the initial substances in the complex composition.
From this graph (Figure 4), it can be seen that MASGA and kinetin reached the maximum yield of complex formation in the ratio of $1: 1$ mol. For complexes in molar ratios of $1: 1$, the stability constant of the complex was calculated using the following formula (1) (Babko et al., 1955).

$$
\mathrm{K}=\frac{\Delta \mathrm{A}_{0} \cdot \Delta \mathrm{A}_{1}}{\mathrm{c}\left(\Delta \mathrm{A}_{0}-\Delta \mathrm{A}_{1}\right)^{2}}
$$

where $\mathrm{c}$ is the concentration of the substance, $\Delta \mathrm{A}_{0}$ is the change of optical density of a fully dissociated complex, $\Delta \mathrm{A}_{1}$ is the change of optical density corresponding to the value on the curve.

As a result, it was determined that the stability constant of the MASGA: kinetin complex is $(7.90 \pm 0.1)^{*} 10^{5} \mathrm{~K}, \mathrm{M}^{-1}$. Using the value of these stability constants $(\mathrm{K})$, it was found that the Gibbs free energy of the resulting complex equals to (2) $(3.30 \pm 0.1)^{*}$ $10^{-4} \Delta \mathrm{G}, \mathrm{J} / \mathrm{mol}$ (Yakovishin et al., 2017).

$$
\Delta \mathrm{G}=-2,3 \mathrm{RT} \lg \mathrm{K}(2)
$$

Based on this method, the stability constant of the MASGA: Adenine complex $\left((2.07 \pm 0.1) * 10^{5} \mathrm{~K}, \mathrm{M}^{-1}\right)$ and the Gibbs free energy values $\left((2.98 \pm 0.1) * 10^{-4} \Delta \mathrm{G}, \mathrm{J} / \mathrm{mol}\right)$ were calculated.

\section{Discussion}

The difference in the frequency of valence vibrations of $\mathrm{OH}$ groups was $29 \mathrm{~cm}^{-1}$, which indicates that hydrogen bonds are involved in the complex formations. In addition, a sharp decrease in the intensity of the NH group vibrations in the region of 3395-3055 $\mathrm{cm}^{-1}$ shows the formation of a complex ion-dipole $\left(-\mathrm{NH}_{3}+\ldots . \mathrm{O}-\mathrm{H}\right.$, $\mathrm{H}+\mathrm{OH},-\mathrm{COOH}-$, except hydrogen bonds) interactions.

The above results showed that the stability of the complex formed by MASGA with kinetin is higher than the stability of the complex formed with adinine (K (MASGA: Kinetin)> K (MASGA: Adinin)).

There are some reports in literature, showing the preparation of GA complexes with kinetin and determination of its stability constant $\left((5.07 \pm 0.1)^{*} 10^{-5}\right)$ as well as the Gibbs free energy $(3.25 \pm 0.1)^{*}$ $10^{-4}$ ) (Dzhuraev et al., 2020). We have found that the kinetin complexes obtained with GA and MASGA were very close in stability reported in literature. In addition, the proximity of the numerical values of the Gibbs free energy indicates that the processes of complex formation also go in the same direction.

\section{Conclusion}

For the first time, supramolecular complexes of GA, MASGA with adenine and kinetine, the complex formation process is discussed based on the methods of optical spectroscopy (UV-, IR-). The stability constants of the obtained complexes in aqueous solutions and the Gibbs free energy have been determined. The stability constants of the complexes have been found as (MASGA: adinine) $(2.07 \pm 0.1) * 10^{5} \mathrm{M}^{-1}$, MASGA: kinetine $(5.07 \pm 0.1) * 10^{5}$, respectively. It has been shown that the molar ratio of components in complexes of MASGA with adenine and kinetine is 1:1. supramolecular complexes are formed by hydrogen bonds and are stabilized by weak intermolecular interactions.

\section{Conflict of interest}

The authors declare no conflicts of interest relevant to this article. 


\section{References}

Babko, A.K. (1955). Physicochemical analysis of complex compounds in solutions. A.K. Babko. Kiev: Publishing House of the Academy of Sciences of the Ukrainian, SSR, pp:328.

Bulatov, M.I.( 1986). A practical guide to photometric methods of analysis MI Bulatov, IP Kalinkin.[5th ed.]. L. Chemistry, pp:432.

Dzhuraev, T.A.; Esanov, R.S.; Gafurov, M.B. and Kushiev, Kh. (2020) Physicochemical characteristics of supramolecular complexes of glycyrrhizic acid with phytohormones. Biochemical and Biomolecular Technology, 2:66-70.

Hwang, I.; Sheen, J. and Muller, B. (2012). Cytokinin signaling networks. Annu. Rev. Plant Biol., 63:353-380.

Kondratenko, R.M.; Baltina, L.A.; Mikhailova, L.R.; Danilov, V.T.; Gabbasov, T.M.; Murinov, Yu. I. and Tolstikov, G.A. (2005). Obtaining glycyrrhizic acid and its practically important salts from licorice root extract. Chem. Pharm. Zhurn., 39(2):11-17.

Kondratenko, R.M.; Baltina, L.A.; Mustafina, S.R.; Ismagilova, A.F.; Zarudiy F.S.; Davydova, V.A.; Bazekin, G.V.; Suleimanova, G.F. and Tolstikov, G. (2003). Complex compounds of glycyrrhizic acid with antimicrobial drugs. Chem. Pharm. Zhurn., pp:32-35.

Medetbekov, B.M.; Arystanova, T.A. and Ordabayeva, S.K. (2007). New complex compound of the glycyrrhizinic acid with antibacterial activity. Mater. Of II Inter. conf. on natural products: chemistry, technology and medicinal perspectives. Almaty (Kazakhstan), pp: 147 .

Naseem, M.; Wolfling, M. and Dandekar, T. (2014). Cytokinins for immunity beyond growth, galls and green islands. Trends Plant Sci., 19(8):307.

Stolyarova, O.V.; Farrakhova, G.F.; Baltina, (Jr.) L.A.; Gabbasov, T.M.; Bashirova R.M.; Kondratenko, R.M. and Baltina, L.A. (2008). Isolation of glycyrrhizic acid and its monoammonium salt from the roots and rhizomes of Korzhinsky licorice (Glycyrrhiza korshinskyigrig). Bulletin of the Bashkir University, 13(2):256-258.

Tolstikov, G.A.; Baltina, L.A.; Murinov Yu. I.; Davydova, V.A.; Tolstikova, T.G.; Bondarev, A.I.; Zarudiy, F.S. and Lazareva, D.N. (1991). Complexes of $\beta$ glycyrrhizic acid with non-steroidal anti-inflammatory drugs as new transport forms. Chem. Pharm. Zhurn., 2:29-32.
Tolstikov, G.A.; Baltina, L.A; Grankina, V.P, Kondratenko, R.M.; Tolstikova, T.G. (2007). Licorice: Biodiversity, Chemistry, Medical Applications. Novosibirsk: Geo., pp:311.

Tolstikova, T.G.; Tolstikov, A.G. and Tolstikov, G.A. (2007). On the way to low-dose drugs. Bulletin of the Russian Academy of Sciences., 10:867-874.

Yakovishin, L. A.; Grishkovets, V.I. and Korzh, E. N. (2017). Supramolecular complex of monoammonium salt of glycyrrhizic acid (glycyram) with caffeine. Scientific notes of the V.I.Vernadsky Crimean Federal University. Biology Chemistry, 3(69):270-277.

Yakovishin, L. A.; Grishkovets, V.I. and Korzh, E.N. (2017). Supramolecular complex of monoammonium salt of glycyrrhizic acid (glycyram) with caffeine. Scientific notes of the V.I.Vernadsky Crimean Federal University. Biology Chemistry, 3(69):270-277.

Yakovishin, L.A. and Grishkovets, V.I. (2019). Molecular complex of quercetin with glycyram: Spectrophotometric analysis. Scientific notes of the V.I.Vernadsky Crimean Federal University. Biology Chemistry, 5(71):262-267.

Yakovishin, L.A.; Grishkovets, V.I. and Korzh, E.N. (2014). Supramolecular complexes of ivy and licorice triterpene glycosides with streptocide. Scientific notes of the Tavrichesky National University named after VI Vernadsky Series. Biology Chemistry, 27(66):204-210

Yakovishin, L.A.; Grishkovets, V.I. and Korzh, E.N. (2016). Supramolecular complexes of ivy and licorice triterpene glycosides with Lhistidine. Scientific notes of the V.I. Vernadsky Crimean Federal University. Biology Chemistry, 2(68):99-106

Yakovishin, L.A.; Groshkovets, V.I. and Korzh, E.N. ( 2017). Supramolecular complex of Glycyrrhizic acid monoammonium salt (glycyrs) with caffeine. Scientific notes of the Crimean Federal University. V.I. Vernadsky. Biology Chemistry, 3(69):270-277.

Yakovishin, L.A.; Groshkovets, V.I. and Korzh, E.N. (2014). Supramolecular complex of glycyrrhizic acid monoammonium salt (glycyrs) with arginine and glycine. Scientific notes of the Crimean Federal University. V.I. Vernadsky. Biology Chemistry, 27(66):131-137. 